\title{
DYNAMIC PROJECTION OF CLIMATE CHANGE SCENARIOS ON ABOVEGROUND CARBON STORAGE OF TROPICAL TREES IN WEST PAPUA, INDONESIA
}

\author{
Sandhi Imam Maulana* and Yohannes Wibisono \\ Environmental and Forestry Research and Development Institute at Manokwari \\ Jl. Inamberi, Susweni PO BOX 159, Manokwari 98313-Papua Barat, Indonesia \\ Received: 25 December 2015, Revised: 4 April 2017, Accepted: 6 April 2017
}

DYNAMIC PROJECTION OF CLIMATE CHANGE SCENARIOS ON ABOVEGROUND CARBON STORAGE OF TROPICAL TREES IN WEST PAPUA, INDONESIA. Through photosynthetic activities, tropical forest ecosystems capture and store the most significant carbon emissions in the form of biomass compared with other types of vegetation, and thus play a highly crucial part in dealing with climate change. However, such important role of tropical forest is very fragile from extreme changes in temperature and precipitation, because carbon storage in forest landscape is strongly related to those climate variables. This paper examines the impacts of future climate disturbances on aboveground carbon storage of three tropical tree species, namely Myristica sp., Palaquium sp., and Sysygium sp. through "what if" scenarios evaluation using Structural Thinking and Experimental Learning Laboratory with Animation (STELLA). Results highlighted that when the dynamic simulation was running with five IPCC's climate change scenarios (Constant year 2000 concentrations, B1, A1T, A2, and A1F1) for 200 years simulation period, then moderate climate change scenarios occured, such as B1 and A1T, would have already caused significant statistical deviation to all of those tree species. At the worst level of $\mathrm{A} 1 \mathrm{~F} 1$, the $4^{\circ} \mathrm{C}$ temperature was coupled with $20 \%$ reduction in precipitation. Palaquium sp. showed the highest reduction of aboveground carbon storage with about $17.216 \%$ below its normal value. This finding implies the negative climate feedbacks should be considered seriously to ensure the accuracy of long term forest carbon accounting under future climate uncertainty.

Keywords: Climate change, aboveground carbon storage, West Papua, STELLA

PROYEKSI DINAMIS BERBAGAI SKENARIO PERUBAHAN IKLIM TERHADAP SIMPANAN KARBON DI ATAS PERMUKAAN TANAH PADA BERAGAM JENIS POHON TROPIS DI PAPUA BARAT, INDONESIA. Melalui fotosintesis, ekosistem butan menangkap dan menyimpan emisi karbon dalam bentuk biomassa yang paling besar dibandingkan dengan jenis vegetasi lain, dan memainkan peran yang sangat penting dalam menangani perubahan iklim. Namun demikian, peran penting tersebut secara signifikan dapat terganggu oleh perubahan temperatur dan curah bujan yang ekstrem karena penyimpanan karbon di lanskap butan sangat terkait dengan variabel iklim tersebut. Tulisan ini mempelajari dampak gangguan iklim di masa depan pada penyimpanan karbon di atas tanah pada tiga

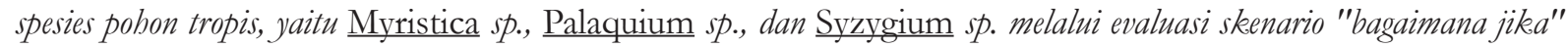
berbasis STELLA. Hasil penelitian menunjukkan babwa ketika simulasi dinamis dijalankan mengikuti lima skenario perubahan iklim oleh IPCC untuk periode simulasi 200 tahun, terlihat bahwa skenario moderat, seperti B1 dan A1T, telah menyebabkan simpangan yang signifikan untuk. ketiga spesies pohon tropis tersebut. Pada skenario terburuk. A1F1

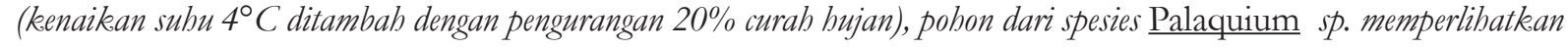
tingkat penurunan tertinggi pada simpanan karbon di atas tanah dengan sekitar 17,216\% kurang dari nilai normalnya. Hal ini menunjukkan bahwa umpan balik negatif dari perubahan iklim barus diperbitungkan untuk memastikan keakuratan penghitungan karbon butan jangka panjang di bawah ketidakpastian iklim di masa depan.

Kata kunci: Perubahan iklim, simpanan karbon diatas tanah, Papua Barat, STELLA

*Corresponding author: frost_stick@yahoo.com 


\section{INTRODUCTION}

It has been widely recognized that carbon dioxide $\left(\mathrm{CO}_{2}\right)$ constitutes for more than half of the total anthropogenic greenhouse gasses emissions. Through photosynthesis procedures, tropical forest ecosystems capture and store the most significant carbon emissions in the form of biomass compared with other types of vegetation, and thus it plays a highly crucial part in dealing with climate change. As reported by Sha et al. (2015), about 55\% of annual net primary production of biomass across the globe is estimated to take place in the tropics. Nevertheless, some authors, such as Ricker, Gutiérrez-García, and Daly (2007); Dai et al. (2014); and Ma et al. (2014), have noted that such important role of tropical forest is very vulrnerable to extreme changes in temperature and precipitation since carbon storage in forest landscape is much related to those climate variables. Dai et al. (2014) also added how the changes in temperature and/or precipitation will drive carbon dynamics in forest ecosystem.

Nowadays, what is alarming is that the earth's mean temperature has already increased by $0.6^{\circ} \mathrm{C}$ over the last 100 years, and that further climate change may raise global temperature within the next century by another $4^{\circ} \mathrm{C}$ (Intergovernmental Panel on Climate Change [IPCC], 2007). Therefore, there is a need to assess how the carbon dynamics of tropical trees may react to climate change as the report has also suggested a negative impact of warming in tropical forests from decreased photosynthetic activity.

Previously, some researchers have carried out studies related to climate influence on carbon accumulation in forest ecosystems. Hunter (2015) assessed the influences of temperature and rainfall on carbon stocks across Northeastern part of New South Wales, Australia, while Limbu and Koirala (2017) examined the climate influence at different altitudinal gradients on both below and aboveground carbon storage. Recently, $\mathrm{Ma}$ et al. (2014) predicted the impacts of climate change on aboveground carbon storage rate in Northeastern China. Stinziano and Way, (2014) evaluated the effect of rising temperature on boreal forest. Meanwhile, climate sensitivity of Mediterranean landscape has been investigated by Touchan, Shishov, Meko, Nouiri, and Grachev (2012). Although all of those studies provide important information on the relation between changing climate variables and carbon storage, however, the dynamics of aboveground carbon storage of tropical trees in the eastern part of Indonesia under climate change scenarios are still unclear. Many other researchers had also examined how the carbon stock and biomass accumulation were assessed either using terrestrial or remotely sensed data (Jaya et al., 2012, Achmad, Jaya, Saleh, \& Kuncahyo, 2013; Jaya, 2014).

According to Dominati, Patterson, and Mackay (2010), insufficient knowledge of carbon storage as ecosystem dynamic flow processes may result in the absence of a systematic and flexible method to manage and plan the ecosystem, so that temporal study and analysis of dynamic change of ecosystem service is necessary. Furthermore, Dean, Roxburgh, and Mackey (2003) and Oni, Dillon, Metcalfe, and Futter (2012) contend that dynamic flow modeling and its corresponding analyses are essential in providing a baseline and "what if" scenarios for evaluating effects related to climate disturbances. This paper examines the impacts of future climate disturbances on aboveground carbon storage of three tropical tree species, namely Myristica sp., Palaquium sp. and Syzygium sp. through "what if" scenarios evaluation using Structural Thinking and Experimental Learning Laboratory with Animation (STELLA).

\section{MATERIAL AND METHOD}

\section{A. Study Site}

As depicted in Figure 1, this study was conducted in a concession forest area managed by PT. Manokwari Mandiri Lestari in Teluk Bintuni Regency, West Papua (1057'50"3011'26” S; 132044'59”-134014'49” E). 


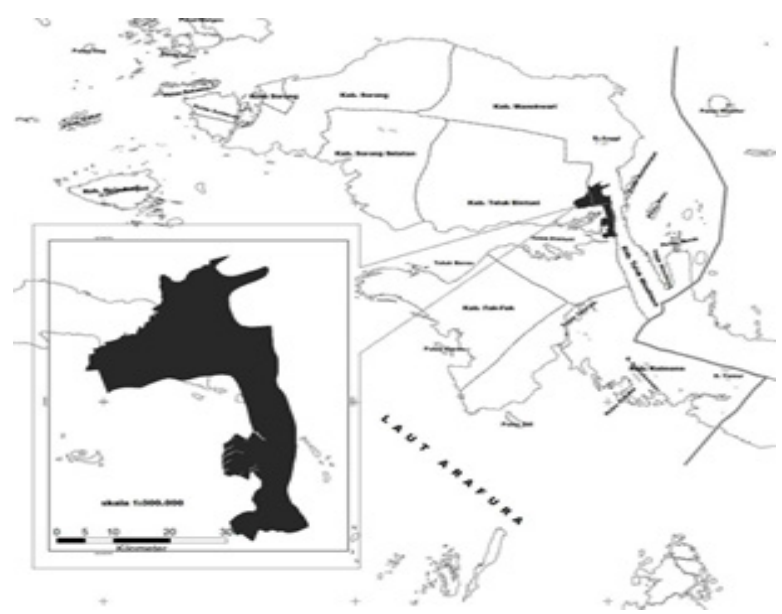

Figure 1. Research site map

This research area is mainly hilly and located about 500 meters above sea level with average humidity approximately $85 \%$. There are three main soil types in the area, namely alluvial, gleysol and podzolic.

\section{B. Model Conceptualization, Calibration and Projection}

As shown in Figure 2, dynamic model structure for simulating relationship between local climate variables and carbon storage in this study was developed using STELLA 9.12, which is principally an object-oriented modeling and simulation software. Algorithm details of this dynamic model are shown in Appendix 1. Conceptually, in this study there are two step sectors in the whole process of carbon sequestration flow structure, which are carbon capture and carbon storage that can last for a long period. Carbon capture refers to the uptake of $\mathrm{CO}_{2}$ from the atmosphere through photosynthetic mechanism and its conversion to biomass, whilst carbon storage refers to the preservation of carbon as biomass in the components of corresponding trees (Sha et al., 2015).

Firstly, in carbon capture sector, through photosynthesis, vegetation converts carbon from the atmosphere to carbohydrate and stores it in different tree organs. This process of carbon capture is related to the process of tree growth (Sha et al., 2015), and it is influenced by climatic factors, particularly temperature and precipitation rate (Theurillat \& Guisan, 2001; Laubhann, Sterba, Reinds, \& Vries, 2009; Allen et al., 2010). In this study, the value of tree growth as a function of time was adjusted based on the value of annual increment calculated by Wahyudi and Anwar (2013), in which Palaquium sp. was grouped into harvested commercial species, while both Myristica sp. and Syyygium sp. were grouped into other commercial unharvested species, as depicted in Table 1. Although in their study, Wahyudi and Anwar (2013) have used the term Mean Annual Increment (MAI), however, according to several other studies such as Vanclay (1994), Avery and Harold (2002), and Pretzsch (2009), it seems that the term Periodic Annual Increment (PAI) is more relevant to represent the growth of tree species in natural forest because basically there is no age information for those natural tree species.

Obtained PAI data, as illustrated in Table 1 , were then used to estimate the tree growth period (TGP) for each $\mathrm{DBH}$ class. For the beginning of the growth period, due to the unavailability of PAI data for DBH class less than $10 \mathrm{~cm}$, the simulation at year 0 was set using initial DBH of $10 \mathrm{~cm}$. From that point forward, TGP was calculated by dividing the interval of each DBH class $(\mathrm{cm})$ with its corresponding PAI (cm/year) as depicted in Table 2.

Afterwards, biomass accumulation into the 

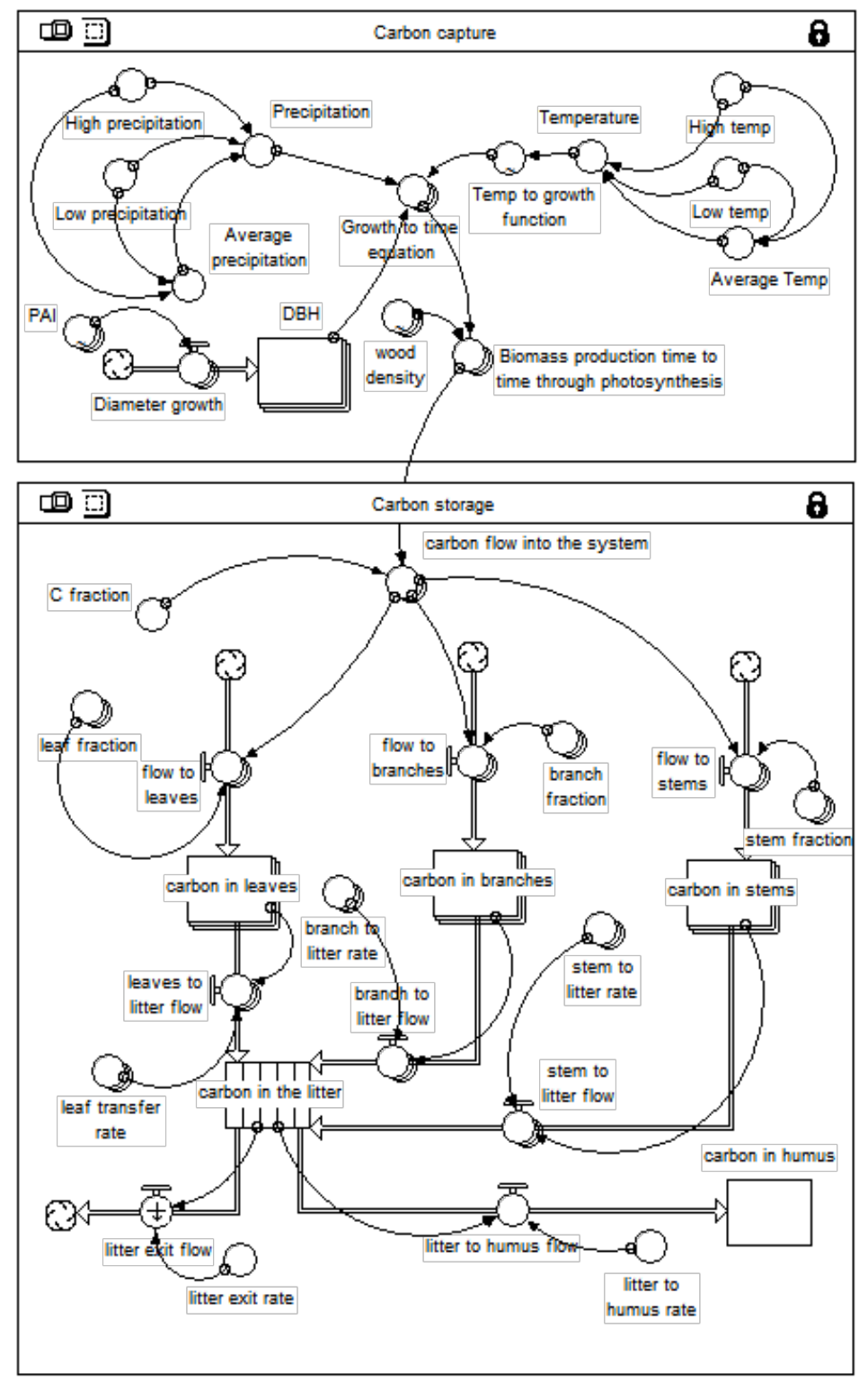

Figure 2. Model structure for simulating climate variables and carbon flows

system through photosynthetic activity was calibrated using locally developed allometric formula (Equation 1), which was specifically designed for mixed tree species in the research area by Maulana, Wibisono, and Utomo (2016). $\log (T A G B)=-0.267+2.23 \log (D B H)+0.649 \log (W D) \ldots(1)$

where:

TAGB $=$ total aboveground biomass $(\mathrm{kg} /$ tree $)$

$\mathrm{DBH}=$ diameter at breast height $(\mathrm{cm})$

WD = wood density or specific gravity $\left(\mathrm{gr} / \mathrm{cm}^{3}\right)$

In the meantime, in order to obtain values of wood density (WD) and biomass fractions allocated to leaves, branches and stems, harvest method was applied to 31 trees of Myristica sp., Palaquium sp. and Syzygium sp. Compared to wood density values from Soerianegara and Lemmens (1993), and Lemmens, Soerianegara, and Wong (1995), results of measurements in this study is shown in Figure 3. It illustrates a highly rational wood density for each species since it is mentioned that the range of wood density for Myristica sp., Palaquium sp., and Syzygium sp. are $0.40-0.65 \mathrm{gr} / \mathrm{cm}^{3}, 0.45-0.51 \mathrm{gr} /$ $\mathrm{cm}^{3}, 0.56-0.83 \mathrm{gr} / \mathrm{cm}^{3}$ respectively.

Moving on to the second sector of 
Table 1. Tree growth

\begin{tabular}{cccc}
\hline $\begin{array}{c}\text { DBH Class } \\
(\mathrm{cm})\end{array}$ & Palaquium sp. & Myristica sp. & Syzygium sp. \\
\cline { 2 - 4 } & PAI (cm/year) & PAI (cm/year $)$ & PAI (cm/year) \\
\hline $10-19$ & 0.2158 & 0.2108 & 0.2108 \\
$20-29$ & 0.3408 & 0.3458 & 0.3458 \\
$30-39$ & 0.4058 & 0.4208 & 0.4208 \\
$40-49$ & 0.4108 & 0.4358 & 0.4358 \\
$50-59$ & 0.3558 & 0.3908 & 0.3908 \\
$>60$ & 0.2408 & 0.2858 & 0.2858 \\
\hline
\end{tabular}

Source: Wahyudi and Anwar (2013)

Table 2. Calculation of Tree Growth Period (TGP) and its simulation time step

\begin{tabular}{|c|c|c|c|c|c|c|c|}
\hline \multicolumn{2}{|l|}{ DBH class } & $10-19 \mathrm{~cm}$ & $20-29 \mathrm{~cm}$ & $30-39 \mathrm{~cm}$ & $40-49 \mathrm{~cm}$ & $50-59 \mathrm{~cm}$ & \multirow{2}{*}{$>60 \mathrm{~cm}$} \\
\hline \multicolumn{2}{|l|}{ TGP calculation } & (19-10)/PAI & (29-20)/PAI & (39-30)/PAI & $(49-40) / \mathrm{PAI}$ & (59-50)/PAI & \\
\hline Palaquium sp. & $\begin{array}{l}\text { TGP } \\
\text { Time step }\end{array}$ & $\begin{array}{c}42 \text { years } \\
\text { year } 1 \text { to } 42\end{array}$ & $\begin{array}{c}26 \text { years } \\
\text { year } 43 \text { to } 69\end{array}$ & $\begin{array}{c}22 \text { years } \\
\text { year } 70 \text { to } 92\end{array}$ & $\begin{array}{c}22 \text { years } \\
\text { year } 93 \text { to } 115\end{array}$ & $\begin{array}{c}25 \text { years } \\
\text { year } 116 \text { to } 141\end{array}$ & $\geq$ year 142 \\
\hline Myristica sp. & $\begin{array}{l}\text { TGP } \\
\text { Time step }\end{array}$ & $\begin{array}{c}43 \text { years } \\
\text { year } 1 \text { to } 43\end{array}$ & $\begin{array}{c}26 \text { years } \\
\text { year } 44 \text { to } 70\end{array}$ & $\begin{array}{c}21 \text { years } \\
\text { year } 71 \text { to } 92\end{array}$ & $\begin{array}{c}21 \text { years } \\
\text { year } 93 \text { to } 114\end{array}$ & $\begin{array}{c}23 \text { years } \\
\text { year } 115 \text { to } 138\end{array}$ & $\geq$ year 139 \\
\hline Syzygium sp. & TGP & 43 years & 26 years & 21 years & 21 years & 23 years & $\geq$ year 139 \\
\hline
\end{tabular}

carbon storage, carbon influx is split in three directions, namely stems, branches and leaves. As depicted in Figure 4, result from destructive measurements to obtain biomass fraction for each species adapted from Maulana et al. (2016) have illustrated the major biomass storage in a tree, followed by branches and leaves. Meanwhile, carbon content in tree components was determined using biomass to carbon ratio value established by Hairiah and Rahayu (2007) that was $46 \%$, so that carbon quantity in each component was defined by multiplying the dry weight of corresponding components by the percentage of carbon amount.

Calibration for carbon flow into the system and litter flow rate were conducted repeatedly until there was no significant difference between actual storage value approximation and dynamic modelling results based on the value of two samples t-test using MINITAB 14.0 software. In this study, actual carbon storage value approximation is defined as the value of total aboveground carbon stored in trees over time approached solely based on local allometric formula (Equation 1) using $\mathrm{DBH}$ adjusted by diameter growth periodic calculation and WD from field measurement. On the other hand, dynamic modeling carbon storage value is defined as the value of total aboveground carbon stored in tree over time calculated based on STELLA dynamic model structure as depicted in Figure 2.

Initial dynamic simulation was set based on climate time series data of perceived temperature and precipitation for the last decade (2005-2015) that were supplied by the National Climatic Data Center (NCDC) from its nearest climate station in Teluk Bintuni Regency, West Papua. The trends of these climate variables data are illustrated in Figure 5. According to these climatic trends, the annual range of temperature and precipitation in the research area were about $22.9^{\circ} \mathrm{C}$ to $31.5^{\circ} \mathrm{C}$ and $1042.7 \mathrm{~mm} /$ year to $3333.5 \mathrm{~m} /$ year respectively.

Subsequently, projections toward future probabilities of climate disturbances were 


\begin{tabular}{|c|c|c|c|}
\hline \multirow{5}{*}{$\begin{array}{l}0.90 \\
0.80 \\
0.70 \\
0.60 \\
0.50 \\
0.40 \\
0.30 \\
0.20\end{array}$} & \multicolumn{3}{|r|}{$\square$} \\
\hline & \multirow{2}{*}{\multicolumn{2}{|c|}{ 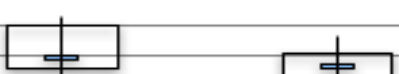 }} & \\
\hline & & & \\
\hline & \multicolumn{3}{|c|}{7} \\
\hline & Myristica & Palaquium & Syzygium \\
\hline Average & 0.49 & 0.46 & 0.77 \\
\hline Q1 & 0.45 & 0.41 & 0.72 \\
\hline Min & 0.41 & 0.33 & 0.54 \\
\hline Max & 0.63 & 0.56 & 0.80 \\
\hline Q3 & 0.60 & 0.50 & 0.78 \\
\hline
\end{tabular}

Figure 3. Measured wood density

Table 3. Scenarios of future climate conditions at the end of $21^{\text {st }}$ century (2090-2099)

\begin{tabular}{lccc}
\hline \multirow{2}{*}{ Scenario } & \multicolumn{2}{c}{ Temperature increase $\left({ }^{\circ} \mathrm{C}\right)$} & $\begin{array}{c}\text { Precipitation change } \\
\text { Average }\end{array}$ \\
\hline Constant year 2000 & 0.6 & $0.3-0.9$ & \\
concentrations & 1.8 & $1.1-2.9$ & $-20 \%$ \\
B1 & 2.4 & $1.4-3.8$ & \\
A1T & 3.4 & $2.0-5.4$ & \\
A2 & 4.0 & $2.4-6.4$ & \\
A1FI & Likely range & \\
\hline
\end{tabular}

Source: Intergovernmental Panel on Climate Change [IPCC] (2000)

conducted using scenarios described in Special Report on Emission Scenarios (SRES) by Intergovernmental Panel on Climate Change [IPCC] (2000). Details on climate scenarios involved in this study are depicted in Table 3. Overall, according to Intergovernmental Panel on Climate Change [IPCC] (2000), the first scenario (year 2000) is constant assumes that greenhouse gases concentration is held fixed at year 2000 levels. Hence, this scenario put the lowest projection of temperature increase at $0.6^{\circ} \mathrm{C}$. The $\mathrm{B} 2$ scenario describes a world with less rapid economic and population development due to increasing attention to environmental sustainability. The A1T scenario illustrates a future world with rapid introduction of new technologies of non-fossil energy sources. The A2 scenario considers fragmented technological and economic development. Lastly, The A1FI scenario puts more emphasis on the intensive development of fossil fuel based industries, so that this scenario gets the highest estimate of temperature increase of $4^{\circ} \mathrm{C}$. In the meantime, as suggested in Gardner and Urban (2003), in order to examine the impact of future climate disturbances on carbon storage of each species, results from dynamic simulations based on IPCC scenarios were then compared to results of their dynamic modelling of actual carbon storage harnessing their percentage value of deviation (Equation 2 ), while statistically examined based on paired t-test mechanism.

$$
\mathrm{S}=100 *\left(\frac{\sum_{\mathrm{i}=1}^{\mathrm{n}} \mathrm{D}_{\mathrm{i}}-\sum_{\mathrm{i}=1}^{\mathrm{n}} \mathrm{B}_{\mathrm{i}}}{\sum_{\mathrm{i}=1}^{\mathrm{n}} \mathrm{B}_{\mathrm{i}}}\right)
$$

where:

$\mathrm{S}=$ percentage value of deviation

$\mathrm{B}_{\mathrm{i}}=$ dynamic modeling of actual carbon stored in tree-i

$\mathrm{D}_{\mathrm{i}}=$ its projection based on IPCC scenario set in the dynamic model

$n=$ number of observations 


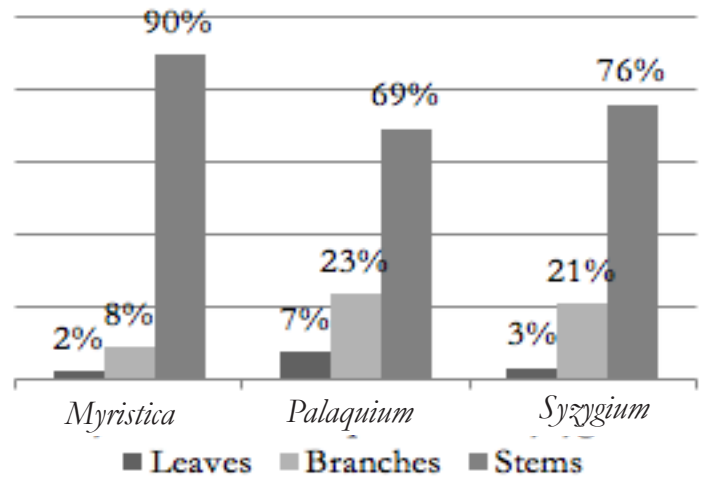

Figure 4. Observed biomass fraction (Source: adapted from Maulana et al., 2016)
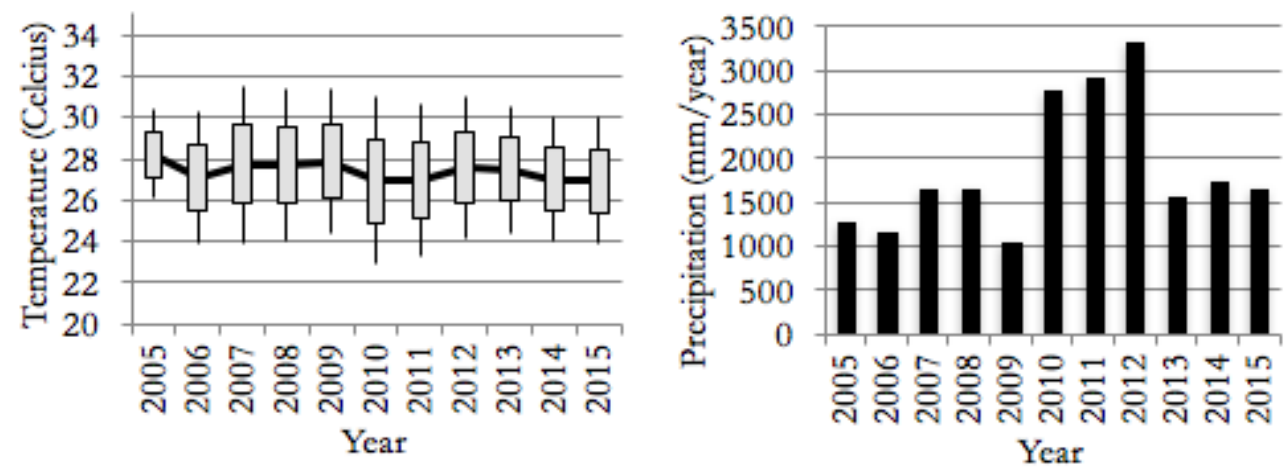

Figure 5. Baseline data for temperature and precipitation as observed by NCDC

\section{RESULT AND DISCUSSION}

\section{A. Actual Approximation vs Dynamic Modeling of C Storage at Baseline Condition}

To assess the accuracy and enhance projection confidence for future "what if" scenarios as described in Bugmann (2001) and Ford (2010), actual approximations of carbon storage for each species were initially evaluated against its corresponding dynamic modelling result set at baseline conditions. This evaluation is essential to show that there was no significant difference between actual carbon sequestered by the system and its dynamic estimation (Gardner \& Urban, 2003; Ford, 2010).

In the previous study, the prototypes were also assessed by using some calculations for cost analysis. The result of the calculation for both prototypes is given in Table 4 .

As depicted in Table 4, the result of t-test, shows that $\mathrm{t}$-values are significantly below their t-table at 95\% confidence interval; and P-values $(\mathrm{P}>0.05)$ also indicate weak evidence against the null hypothesis $\left(\mathrm{H}_{\mathrm{o}}\right)$. This implies that $\mathrm{H}_{0}$ (dynamic modelling is close to the actual approximation of carbon storage, expressing that for each species) are statistically accepted (Gardner \& Urban, 2003). In addition, values of Pearson correlation test $(r)$ between approximation and its corresponding dynamic modelling of actual storage for each species shows a very high and positive correlation. As illustrated in Figure 6, the overall trends of carbon storage for each species formed a common rough sigmoid shaped growth curve, showing that the carbon amount stored increases fast in their early age, while later this trend tends to gradually slow down due to the decrease in carbon capture. 
Table 4. Statistical tests for actual approximation vs dynamic modeling of C storage

\begin{tabular}{|c|c|c|c|c|c|c|c|c|}
\hline \multirow[b]{2}{*}{ Species } & \multirow[b]{2}{*}{ Group comparison } & \multicolumn{7}{|c|}{ t-test at $95 \%$ confidence interval } \\
\hline & & Mean & $\begin{array}{c}\text { SE } \\
\text { Mean }\end{array}$ & DF & t-table & $\mathrm{t}$-value & $\mathrm{p}$-value & $\mathrm{r}$ \\
\hline \multirow{2}{*}{ Myristica sp. } & Actual proxy & 839 & 51 & \multirow{2}{*}{397} & \multirow{2}{*}{1.985} & \multirow{2}{*}{0.46} & \multirow{2}{*}{0.647} & \multirow{2}{*}{0.99} \\
\hline & Dynamic modeling & 806 & 50 & & & & & \\
\hline Palaquium sp. & $\begin{array}{l}\text { Actual proxy } \\
\text { Dynamic modeling }\end{array}$ & $\begin{array}{l}754 \\
725\end{array}$ & $\begin{array}{l}45 \\
44\end{array}$ & 397 & 1.985 & 0.47 & 0.639 & 0.99 \\
\hline Sysygium sp. & Actual proxy & 1019 & 60 & 397 & 1.985 & 0.48 & 0.634 & 0.99 \\
\hline
\end{tabular}
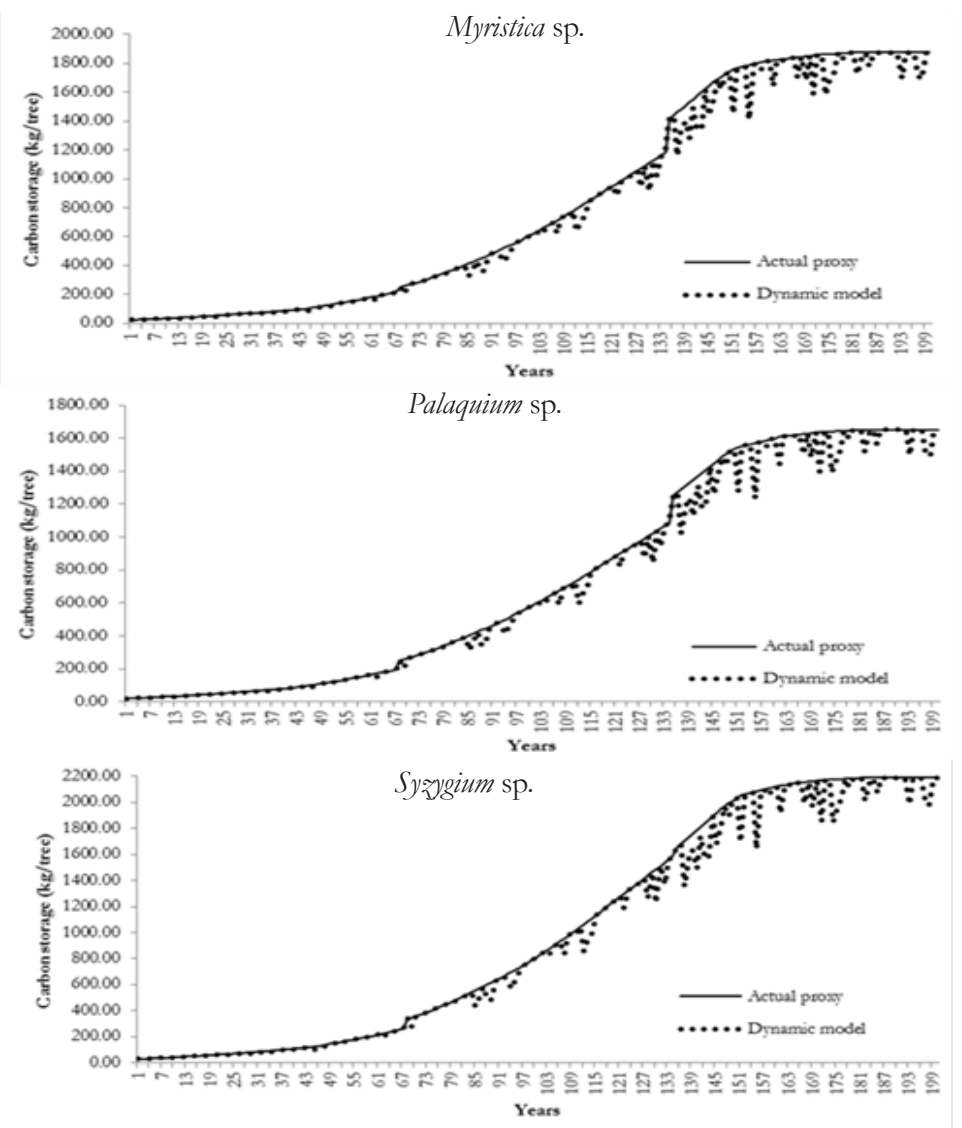

Figure 6. Actual approximation vs dynamic modeling of $\mathrm{C}$ storage at baseline condition

\section{B. Dynamic Projections of Future C Storage Based on IPCC Scenarios}

In general, as illustrated in Figure 7, 8 and 9, there were dynamic fluctuations of carbon storage for each species when climate parameters within the dynamic model were set following future scenarios as described in Intergovernmental Panel on Climate Change [IPCC] (2000). At first, the aboveground carbon storage for each tree species were relatively stable when the model was run based on the "constant year 2000 concentrations" scenario, where the assumption was a $0.6^{\circ} \mathrm{C}$ temperature increase and about $20 \%$ precipitation decrease. Nevertheless, from that point forward, the aboveground carbon stored in the system generally started to decrease when the climate parameters were adjusted to more extreme scenarios, namely B1, AIT, A2, and A1FI. This kind of fluctuation may occur since at warmer 
temperature and lower precipitation compared to normal condition, broadleaf trees tend to decrease their photosynthetic productivity while increase littering pace to sustain their metabolism equilibrium which eventually hamper their growth and reduce carbon storage capacity (Heimann \& Reichstein, 2008; Omeja, Obua, Rwetsiba, \& Chapman, 2012; Wang, Duan, \& Zhang, 2012).

To sum up, the detailed projections of Intergovernmental Panel on Climate Change [IPCC] (2000) climate scenarios on carbon storage for each species from Figure 7, 8 and 9 are shown in Table 5. This table, apparently describes that future rise in temperature and decrease in precipitation rate will reduce carbon storage capacity for all species. Furthermore, climate change will cause the largest impact in scenario $\mathrm{A} 1 \mathrm{~F} 1$ where there is $4^{\circ} \mathrm{C}$ increase in temperature range coupled with $20 \%$ reduction in precipitation. At this scenario, aboveground carbon stored in the trees from species of Myristica sp., Palaquium sp., and Sysygium sp. will decrease approximately $17.213 \%, 17.216 \%$ and $16.062 \%$ respectively during 200 years of simulation period.

Figure 10 shows the projection of $\mathrm{C}$ storage, derived from Table 4. It is clearly shown that Myristica sp., Palaquium sp., and Sysygium sp. are becoming more vulnerable when climate scenario worsens. Moderate climate change scenarios, such as B1 and A1T, have already brought significant statistical deviation to all of those species. In addition to this, looking at
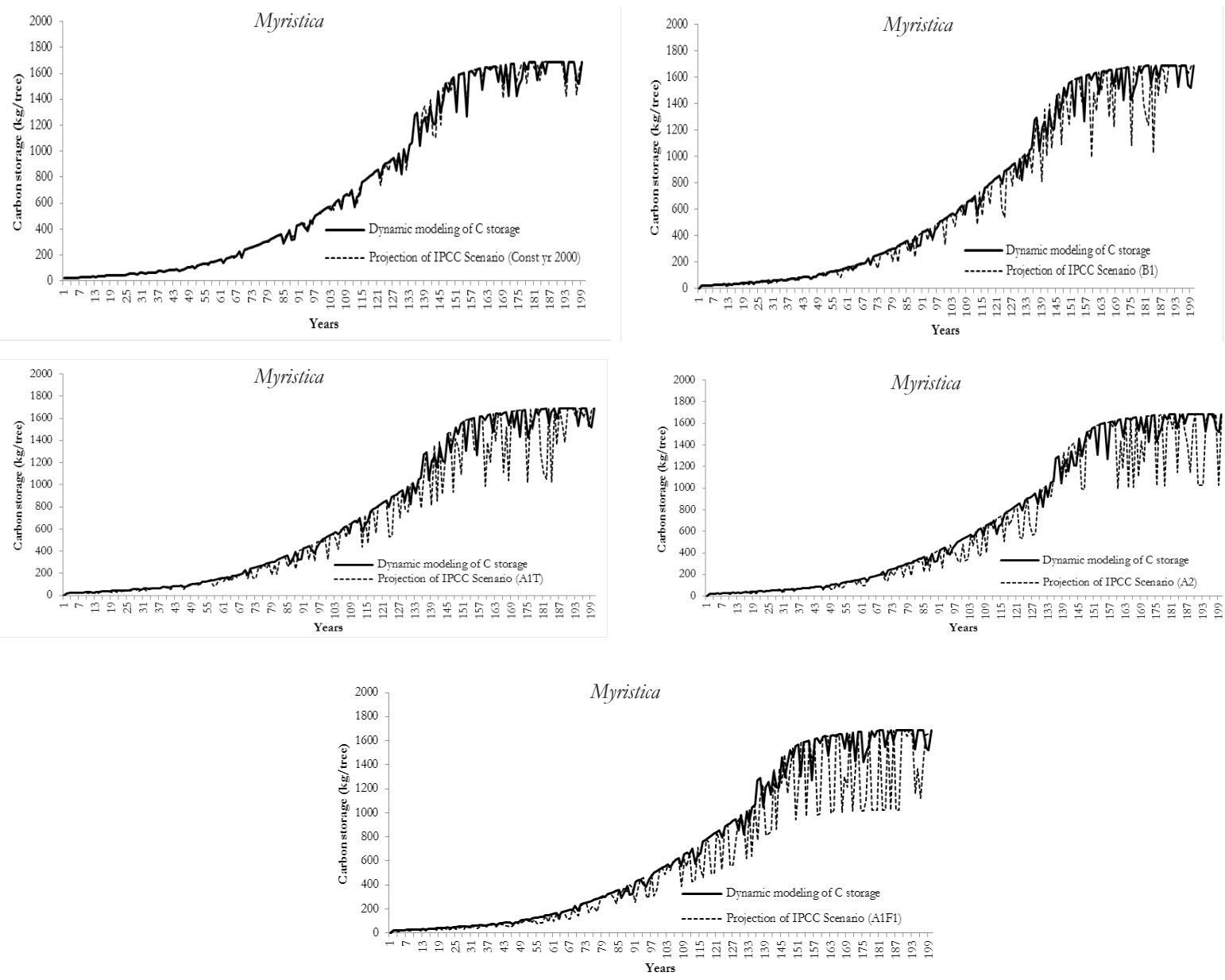

Figure 7. Projection of future climate change scenarios (Constant year 2000 concentrations, B1, A1T, A2, A1F1) on carbon storage of Myristica sp. for 200 years simulation period 

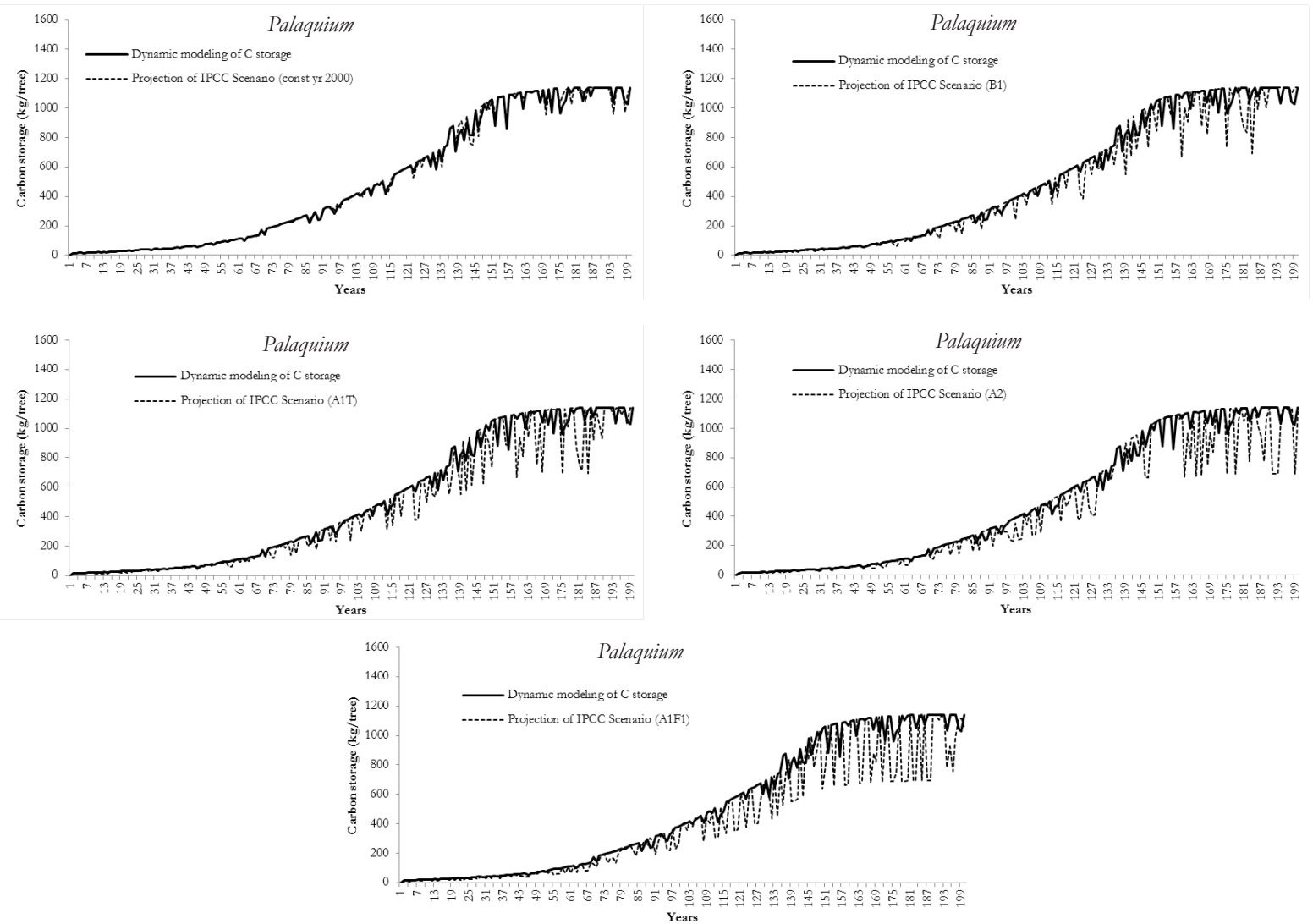

Figure 8. Projection of future climate change scenarios (Constant year 2000 concentrations, B1, A1T, A2, A1F1) on carbon storage of Palaquium sp. for 200 years simulation period

the more extreme climate scenario of $\mathrm{A} 2$ and A1F1, it seems that Sysygium sp. has the lowest decrease in carbon storage, while Palaquium sp. tends to produce the highest rate of decrease compared to the two other trees species. This finding is in agreement with several previous studies which have showed that the growth and productivity of many broadleaf trees with the lowest wood density value among their corresponding groups, is more vulnerable when temperature becomes warmer (Bennett et al., 2013; Coops \& Waring, 2011; Subedi \& Sharma, 2013; Hu, Su, Li, Li, \& Ke, 2015). Taking into account of this notion, compared to Myristica sp. and Syzygium sp. (Table 5, Figure 3), Palaquium sp. has the lowest range of wood density with only $0.33-0.56 \mathrm{gr} / \mathrm{cm}^{3}$ in contrast with Syzygium sp. that has the highest range of wood density with about $0.54-0.80 \mathrm{gr} / \mathrm{cm}^{3}$.

This study noted that although the simulation findings may provide a feasible approach to analyze model dynamics, however, it should be kept in mind that the simulation aboveground carbon storage on various climate change scenarios are complex flow processes. The users may improve the accuracy of the dynamic model by appropriately considering the possible shortcomings, particularly in regard to tree growth calculation. Looking at the periodical annual increment of each tree species (Table 1), it seems that the growth rate are too slow and there is no obvious annual increment difference among them. The PAI for Palaquium sp. is only limited to $0.22-0.41 \mathrm{~cm} /$ year, while Myristica sp. and Syzygium sp. is about $0.21-0.43 \mathrm{~cm} /$ year. Those relatively small annual increments have also been reported by other studies, such as Santoso (2008), and Wahjonoand Anwar (2008), who conducted measurements on permanent sample plots (PSPs) in 199 

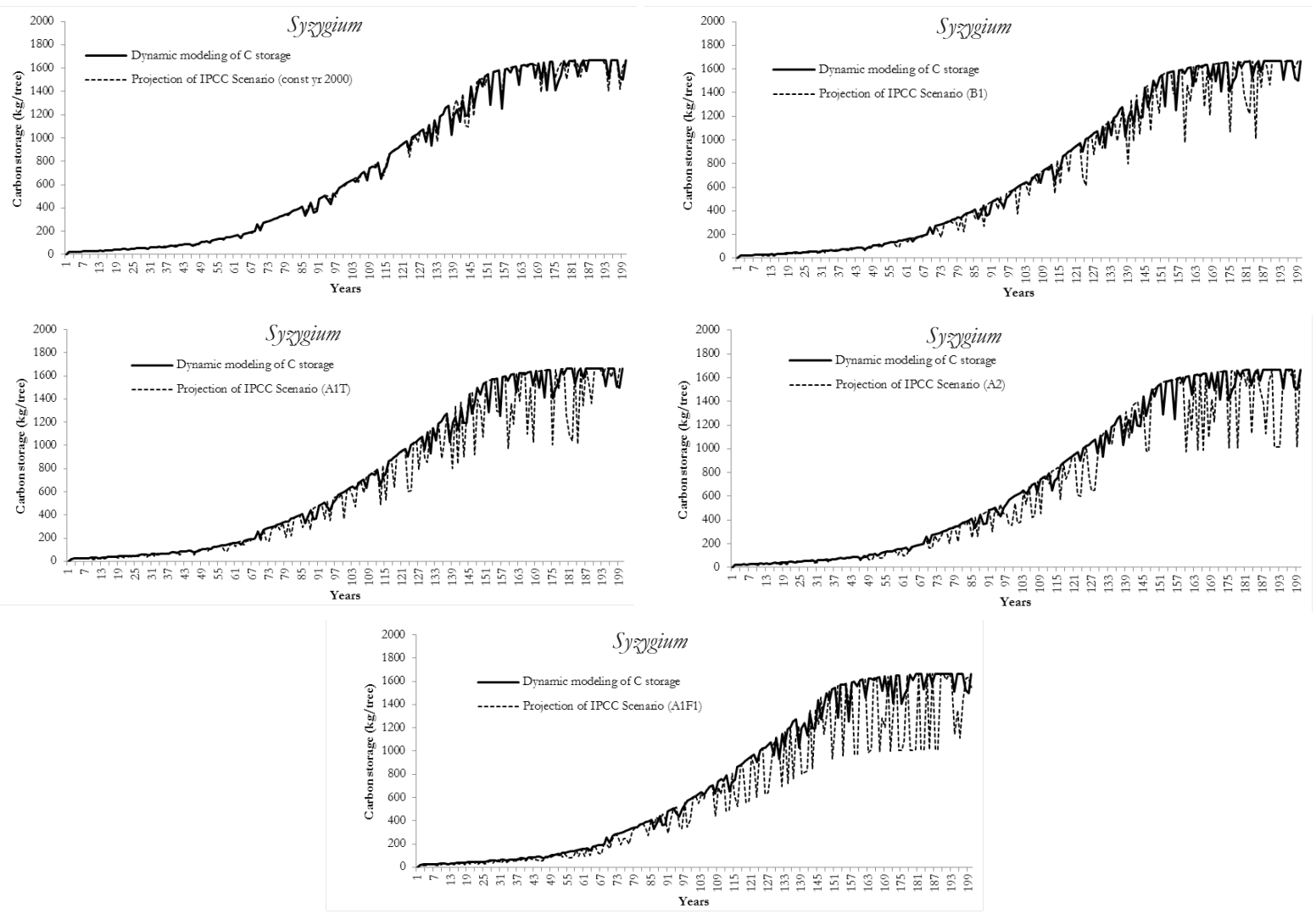

Figure 9. Projection of future climate change scenarios (Constant year 2000 concentrations, B1, A1T, A2, A1F1) on carbon storage of Sysygium sp. for 200 years simulation period

forest consessions across Indonesia. Although the use of tree growth data obtained from permanent sample plots (PSPs) of other studies, as mentioned in the methodology of this study, may inflict bias, however, this kind of approach should be considered as an acceptable alternative because detecting trends in tree growth over natural forest stands is not so simple (Bowman, Brienen, Gloor, Phillips, \& Prior, 2013). In practice, measuring tree growth in PSPs of natural forest are indeed not only very time-consuming to conduct, but also highly logistically demanding since they are often located in remote species rich forets areas (Bowman et al., 2013; Weiskittel, Hann, Kershaw, \& Vanclay, 2011).

\section{CONCLUSION}

From the previous discussion, the following conclusions can be derived. When the dynamic simulation was run the five
IPCC's climate change scenarios (Constant year 2000 concentrations, B1, A1T, A2, and A1F1) for a simulation period of 200 years, the aboveground carbon stored in tree species of Myristica sp., Palaquium sp., and Sysygium sp. will generally decrease. The moderate climate change scenarios, such as B1 and A1T, have already brought significant statistical deviation to all of those tree species. At the worst level of scenario $\mathrm{A} 1 \mathrm{~F} 1\left(4^{\circ} \mathrm{C}\right.$ temperature increase coupled with $20 \%$ reduction in precipitation), the Palaquium sp. may suffer from the highest degree of reduction of aboveground carbon storage with about $17.216 \%$ below its normal value. The Palaquium sp. has the lowest range of wood density with only $0.33-0.56 \mathrm{gr} / \mathrm{cm}^{3}$ compared to Myristica sp. and Syaygium sp. The study concludes that climate negative feedbacks should be considered to ensure the accuracy of long term forest carbon accounting under future climate uncertainties. 
Table 5. C storage deviation based on IPCC SRES climate scenarios

\begin{tabular}{|c|c|c|c|c|c|c|}
\hline & \multirow{2}{*}{ Species } & \multicolumn{5}{|c|}{ IPCC SRES Scenarios } \\
\hline & & Const yr 2000 & B1 & A1T & A2 & A1F1 \\
\hline \multirow{4}{*}{ Myristica sp. } & Deviation (S) & $0.590 \%$ & $-3.687 \%$ & $-6.622 \%$ & $-8.773 \%$ & $-17.213 \%$ \\
\hline & t-value at $95 \% \mathrm{CI}$ & -1.70 & $3.25^{* *}$ & $4.84 * * *$ & $5.04 * * *$ & $7.14 * * *$ \\
\hline & t-table (DF: 199; CI: 95\%) & 1.98 & 1.98 & 1.98 & 1.98 & 1.98 \\
\hline & $\mathrm{p}$-value & 0.090 & 0.001 & $<0.001$ & $<0.001$ & $<0.001$ \\
\hline \multirow{4}{*}{ Palaquium sp. } & Deviation (S) & $0.589 \%$ & $-3.687 \%$ & $-6.622 \%$ & $-8.777 \%$ & $-17.216 \%$ \\
\hline & $\mathrm{t}$-value at $95 \% \mathrm{CI}$ & -1.72 & $3.29 * *$ & $4.90 * * *$ & $5.13^{* * *}$ & $7.23^{* * *}$ \\
\hline & t-table (DF: 199; CI: 95\%) & 1.98 & 1.98 & 1.98 & 1.98 & 1.98 \\
\hline & $\mathrm{p}$-value & 0.086 & 0.001 & $<0.001$ & $<0.001$ & $<0.001$ \\
\hline \multirow{4}{*}{ Syzygium sp. } & Deviation (S) & $0.590 \%$ & $-3.686 \%$ & $-6.621 \%$ & $-8.776 \%$ & $-16.062 \%$ \\
\hline & t-value at $95 \% \mathrm{CI}$ & -1.71 & $3.32^{* *}$ & $4.94 * * *$ & $5.17 * * *$ & $7.28^{* * *}$ \\
\hline & t-table (DF: 199; CI: 95\%) & 1.98 & 1.98 & 1.98 & 1.98 & 1.98 \\
\hline & $\mathrm{p}$-value & 0.089 & 0.001 & $<0.001$ & $<0.001$ & $<0.001$ \\
\hline
\end{tabular}

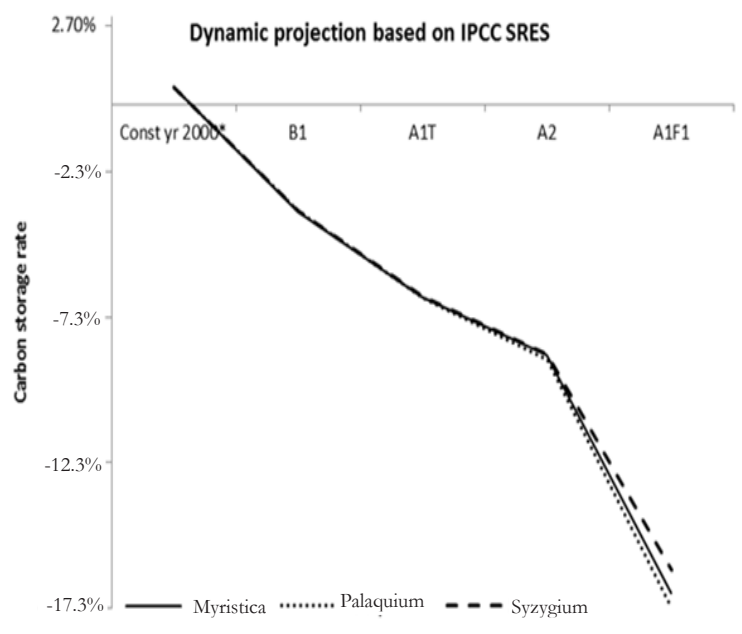

Figure 10. Trend of C storage deviation based on IPCC SRES climate scenarios

\section{ACKNOWLEDGEMENT}

The author is grateful to the Office of Research and Development for Environment and Forestry at Manokwari for providing financial support to conduct this research. Thanks are also due to PT. Mamberamo Alas Mandiri in Mamberamo Regency. Our technicians Mr. Frandon Itlay and Mr. Zeth Luther Rumawak, for field and data measurements assistances, as well as Mr. Ette Panus for providing research site map. Sincerely appreciation is also extended to the anonymous reviewers of significant inputs and correction to the original manuscripts.

\section{REFERENCES}

Achmad, E., Jaya, I. N. S., Saleh, M. B., \& Kuncahyo, B. (2013). Biomass estimation using ALOS PALSAR for identification of lowland forest transition ecosystem in Jambi Province. Jurnal Manajemen Hutan Tropika, 19(2), 145-155. doi:10.7226/jtfm.19.2.145.

Allen, C. D., Macalady, A. K., Chenchouni, H., Bachelet, D., McDowell, N., Vennetier, M., ... Cobb, N. (2010). A global overview of drought and heat-induced tree mortality reveals emerging climate change risks for forests. Forest Ecology and Management, 259(4), 660-684. doi:j.foreco.2009.09.001.

Avery, T. E., \& Harold, B. E. (2002). Forest measurement 
$\left(5^{\text {th }}\right.$ Edition). New York: McGraw-Hill.

Bennett, J. M., Cunningham, S. C., Connelly, C. A., Clarke, R. H., Thomson, J. R., \& Nally, R. Mac. (2013). The interaction between a drying climate and land use affects forest structure and above-ground carbon storage. Global Ecology and Biogeography, 22(12), 1238-1247. doi:10.1111/geb.12083.

Bowman, D. M. J. S., Brienen, R. J. W., Gloor, E., Phillips, O. L., \& Prior, L. D. (2013). Detecting trends in tree growth: not so simple. Trends in Plant Science, 18(1), 11-17. doi:10.1016/j. tplants.2012.08.005.

Bugmann, H. (2001). A review of forest gap models. Climatic Change, 51(3), 259-305. doi:10.1023/A:1012525626267.

Coops, N. C., \& Waring, R. H. (2011). Estimating the vulnerability of fifteen tree species under changing climate in Northwest North America. Ecological Modelling, 222(13), 21192129. doi:10.1016/j.ecolmodel.2011.03.033.

Dai, Z., Birdsey, R. A., Johnson, K. D., Dupuy, J. M., Hernandez-Stefanoni, J. L., \& Richardson, K. (2014). Modeling carbon stocks in a secondary tropical dry forest in the Yucatan Peninsula, Mexico. Water, Air, \& Soil Pollution, 225(1925), 1-15. doi:10.1007/s11270-014-1925-x.

Dean, C., Roxburgh, S., \& Mackey, B. (2003). Growth modelling of Eucalyptus regnans for carbon accounting at the landscape scale. In A. Amaro, D. Reed, \& P. Soares (Eds.), Modelling Forest Systems (pp. 42-54). Cambridge, MA: CABI Publishing.

Dominati, E., Patterson, M., \& Mackay, A. (2010). A framework for classifying and quantifying the natural capital and ecosystem services of soils. Ecological Economics, 69(9), 1858-1868. doi:10.1016/j.ecolecon.2010.05.002.

Ford, A. (2010). Modeling the environment. ( ${ }^{\text {nd }}$ Edition). Washington DC: Island Press.

Gardner，R. H. \& Urban, D. L. (2003). Model validation and testing: past lessons, present concerns, future prospects. In C. D. Ganham, J. J. Cole, \& W. Lauenroth (Eds.), Models in Ecosystem Science. Princeton, NJ: Princeton University Press.

Hairiah, K., \& Rahayu, S. (2007). Pengukuran karbon tersimpan di berbagai macam penggunaan lahan. Bogor: ICRAF.

Heimann, M., \& Reichstein, M. (2008). Terrestrial ecosystem carbon dynamics and climate feedbacks. Nature, 451, 289-292. doi:10.1038/ nature06591.

Hu, Y., Su, Z., Li, W., Li, J., \& Ke, X. (2015). Influence of tree species composition and community structure on carbon density in a subtropical forest. PLOS ONE, 10(8), 1-9. doi:10.1371/ journal.pone.0136984.

Hunter, J. T. (2015). Changes in allometric attributes and biomass of forests and woodlands across an altitudinal and rainfall gradient: What are the implications of increasing seasonality due to anthropogenic climate change ? International Journal of Ecology, 2015, 10 pages. Article ID 208975. doi:10.1155/2015/208975.

Intergovernmental Panel on Climate Change [IPCC]. (2000). IPCC Special report emissions scenarios: Summary for policy makers Intergovernmental Panel on Climate Change.

Intergovernmental Panel on Climate Change [IPCC]. (2007). Climate change 2007. Synthesis report. Retrieved from http://www.ipcc.ch/ publications_and_data/publications_ipcc_ fourth_assessment_report_synthesis_report. htm on July 25, 2015.

Jaya, I. N. S. (2014). The interpolation method for estimating the aboveground biomass using terrestrial-based inventory. Jurnal Manajemen Hutan Tropika, 20(2), 121-130. doi:10.7226/ jtfm.20.2.121.

Jaya, I. N. S., Agustina, T. L., Saleh, M. B., Shimada, M., Kleinn, C., \& Fehrmann, L. (2012). Above ground biomass estimation of dry land tropical forest using ALOS PALSAR in Central Kalimantan, Indonesia. In Proceeding of The $3^{\text {rd }}$ DAAD Workshop on: Forest in Climate Change Research and Policy: The Role of the Forest Management and Conservation in Complex International Setting (pp. 1-19). Dubai (UAE). Retrieved from http://www.uni-geotingen. de/en/67094.html.

Laubhann, D., Sterba, H., Reinds, G. J., \& Vries, W. De. (2009). The impact of atmospheric deposition and climate on forest growth in European monitoring plots: An individual tree growth model. Forest Ecology and Management, 258(8), 1751-1761. doi:10.1016/j. foreco.2008.09.050.

Lemmens, R., Soerianegara, I., \& Wong, W. C. (Eds.) (1995). Plant Resources of South-East Asia 5(2), Timber tress: Minor commercial timbers. Leiden: Backhuys Publishers. 
Limbu, D., \& Koirala, M. (2017). Aboveground and belowground biomass situation of milke-jaljale rangeland at different altitudinal gradient. Our Nature, 9(1), 107-111. doi:10.3126/on.v9i1.5740.

Ma, J., Hu, Y., Bu, R., Chang, Y., Deng, H., \& Qin, Q. (2014). Predicting impacts of climate change on the aboveground carbon sequestration rate of a temperate forest in northeastern china. PLoS ONE, 9(4), 1-15. doi:10.1371/journal. pone.0096157.

Maulana, S. I., Wibisono, Y., \& Utomo, S. (2016). Development of local allometric equation to estimate total aboveground biomass in Papua. Indonesian Journal of Forestry Research, 3(2), 107118. doi:10.20886/ijfr.2016.3.2.107-118.

Omeja, P. A., Obua, J., Rwetsiba, A., \& Chapman, C. A. (2012). Biomass accumulation in tropical lands with different disturbance histories: Contrasts within one landscape and across regions. Forest Ecology and Management, 269, 293-300. doi:10.1016/j.foreco.2011.12.044.

Oni, S. K., Dillon, P. J., Metcalfe, R. A., \& Futter, M. N. (2012). Dynamic modelling of the impact of climate change and power flow management options using stella: Application to the Steephill Falls Reservoir, Ontario, Canada. Canadian Water Resources Journal, 37(2), 125-148(24).doi:10.4296/cwrj3702831.

Pretzsch, H. (2009). Forest dynamics, growth and yield: From measurement to model. Berlin: Springer.

Ricker, M., Gutiérrez-García, G., \& Daly, D. C. (2007). Modeling long-term tree growth curves in response to warming climate: Test cases from a subtropical mountain forest and a tropical rainforest in Mexico. Canadian Journal of Forest Research, 37(5), 977-989. doi:10.1139/X06-304.

Santoso, B. (2008). Kebijakan penerapan multisistem silvikultur pada butan produksi Indonesia. Jakarta: Ditjen Bina Produksi Kehutanan, Departemen Kehutanan.

Sha, P., Gaodi, X., Changshun, Z., Chunlan, L., Shimei, L., Caixia, Z., \& Long, C. (2015). Dynamic simulation of carbon sequestration by Pinus sylvestris var. mongolica. Journal of Resources and Ecology, 6(1), 37-43. doi:10.5814/j. issn.1674-764x.2015.01.005.
Soerianegara, I., \& Lemmens, R. (Eds.) (1993). Plant Resources of South-East Asia 5(1), Timber trees: Major commercial timbers. Wageningen: Pudoc \& PROSEA.

Stinziano, J.R., \& Way, D. A. (2014). Combined effects of rising $\left[\mathrm{CO}^{2}\right]$ and temperature on boreal forests: Growth, physiology and limitations. Botany, 92(6), 425-436. doi:10.1139/cjb-20130314.

Subedi, N., \& Sharma, M. (2013). Climate-diameter growth relationships of black spruce and jack pine trees in boreal Ontario, Canada. Global Change Biology, 19(2), 505-516. doi:10.1111/ gcb.12033.

Theurillat, J. P., \& Guisan, A. (2001). Potential impact of climate change on vegetation in the European Alps: A review. Climate Change, 50(1), 77-109. doi:10.1023/A:1010632015572.

Touchan, R., Shishov, V. V, Meko, D. M., Nouiri, I., \& Grachev, A. (2012). Process based model sheds light on climate sensitivity of Mediterranean tree-ring width. Biogeosciences, 9(3), 965-972. doi:10.5194/bg-9-965-2012.

Vanclay, J. K. (1994). Modelling forest growth and yield: Application to mixed tropical forest. Wallingford, UK: CAB International.

Wahjono, D., \& Anwar. (2008). Prospek penerapan multisistem silvikultur pada unit pengelolaan butan produksi. Bogor: Puslitbang Konservasi Alam, Departemen Kehutanan.

Wahyudi, \& Anwar, M. (2013). Model pertumbuhan pohon-pohon di hutan alam paska tebangan studi kasus pada hutan alam produksi di Kabupaten Kapuas, Kalimantan Tengah. Bionatura: Jurnal Ilmu-Ilmu Hayati dan Fisik, 15(3), 190-195.

Wang, J., Duan, B., \& Zhang, Y. (2012). Effects of experimental warming on growth, biomass allocation, and needle chemistry of Abies faxoniana in even-aged monospecific stands. Plant Ecology, 213(1), 47-55. doi:10.1007/ s11258-011-0005-1.

Weiskittel, A. R., Hann, D. W., Kershaw, J. A., \& Vanclay, J. K. (2011). Forest growth and yield modeling. West Sussex: Wiley-Blackwell. 